\title{
OBITUARIES
}

For the full versions of articles in this section see bmj.com

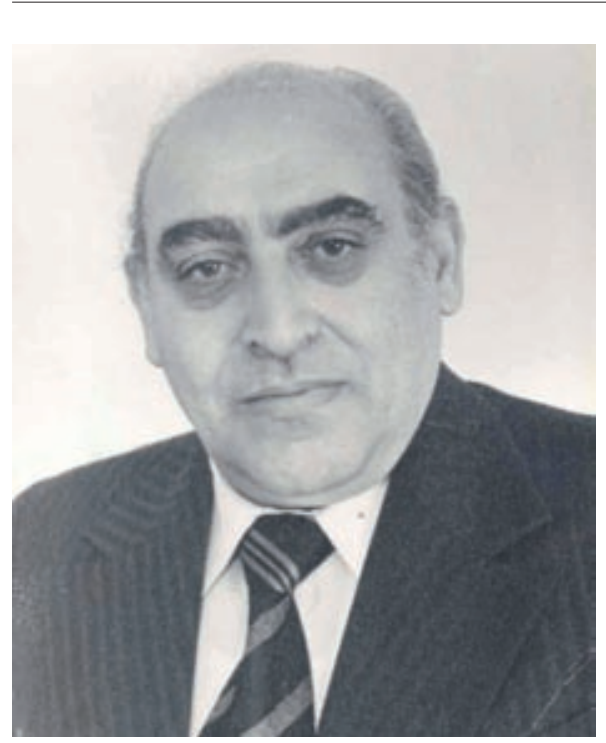

\section{Zinovy Solomonovich Barkagan}

\section{Haematologist who introduced the concept of disseminated intravascular coagulation}

Zinovy Solomonovich Barkagan is internationally recognised for his pioneering research on snake bites and blood coagulation. He wrote about 20 monographs and chapters in Russian manuals on haematology, oncology, and the antiphospholipid syndrome, as well as coauthoring several hundred papers.

Zinovy Barkagan was born in Odessa, a cosmopolitan city on the Black Sea in the south of Russia and the birth place of many outstanding Soviet poets and writers. He explained this phenomenon with his "formula of genius"-everyone in Odessa ate a lot of fish and shrimps. Indeed, Barkagan hesitated in his choice between literature and medicine. He combined his medical studies during the second world war at Alma-Ata in Kazakhstan with evening classes at the journalism faculty of the literary institute evacuated from Moscow.

In 1950 he defended his kandidatskaya dissertation (the Russian equivalent of a $\mathrm{PhD}$ thesis) on vascular reactivity in the cold in arterial hypertension. Owing to an anti-Semitic campaign in the last years of
Stalin's life, he was forced to leave Odessa for Stalinabad (now Dushanbe, Tajikistan), where he worked at a local medical institute as assistant professor and eventually as acting chair of hospital therapy. There he came across numerous deaths from snake bites and the bites of black widow spiders (Latrodectus tredecimguttatus).

The only treatment was to apply a rubber tourniquet, which often resulted in amputation of the hand or leg and seldom saved lives. Barkagan suggested sucking out the venom by mouth. Nowadays this method of treating snake bites is given in all manuals of emergency medicine. To prove the safety of this method Barkagan performed experiments on himself, holding the venom of the Levantine viper (Vipera lebetina) and the carpet viper (Echis carinatus) in his mouth before and after having damaged the mucosa. His doctorskaya dissertation (a second thesis required for professorship in Russia), defended in 1964, was dedicated to diagnosing and treating venom poisoning from snakes and arthropods in Middle Asia. Barkagan considered changes in blood coagulation (hypercoagulation) to be the key point of venom poisoning. He admitted that he first came across this idea from reading Zahira-i Kharazmshahi (The Treasure of the Shah of Khoresm) by Abu Ibrahim Jurjani (1045-1137).

In 1956 Barkagan moved to a newly established medical institute in Barnaul (capital of the Altai region in western Siberia), where he was the propaedeutic (preclinical) chair of internal medicine till 1997. He worked in Barnaul for half a century until his death. He organised the first laboratory to diagnose and treat impairments of haemostasis, and for many years it was the only one in the eastern part of the former Soviet Union, later becoming the Siberian Centre for Haemophilia and the Altai Haematological Centre.

Barkagan suggested treating disseminated intravascular coagulation with massive transfusion of serum (plasma) instead of whole blood. He also emphasised the role of disseminated intravascular coagulation in sepsis. He viewed sepsis as an infection that results in the formation of microthrombi and requires huge doses of antibiotics and serum transfusion or plasmapheresis.

The efficacy of treating the crush syn- drome with plasmapheresis, frozen serum, and heparin was demonstrated during the earthquake in Armenia in 1989. It helped to avoid amputation and achieved a tenfold decrease in acute renal failure and death.

Barkagan and his colleagues also contributed to the diagnosis and treatment of arthropathies in haemophilia. They described a secondary rheumatoid syndrome in haemophilia (known as the Barkagan-Egorova syndrome) and developed an original method of rehabilitation after haemophilic haemorrhages using external fixation techniques.

Two decades ago he started his fight against habitual miscarriages. Up to $80 \%$ of affected women have the antiphospholipid syndrome. Plasmapheresis and heparin during the whole pregnancy successfully allow carriage to term in all such cases. Women from many countries, including the United States and Sweden, came to Barnaul to give birth, but now this treatment is routine.

Barkagan was an honoured science worker of the Russian Federation (1982), a state prize laureate of the USSR (1987), a corresponding member of the Russian Academy of Medical Sciences (1993), a director of the Altai branch of the Haematological Scientific Centre of the Russian Academy of Medical Sciences, doctor honoris causa of the University of Minnesota (USA), and an honorary citizen of Barnaul.

He founded a haematological school. Thirty two of his pupils defended doctorskaya and 82 kandidatskaya dissertations. His lifestyle contradicted conventional dogmas. $\mathrm{He}$ was a chainsmoker, neglected sports, worked at night, and did not eat much. Until his last days he preserved a childlike capacity for amazement.

His wife, Ida Mikhailovna (née Proector), a paediatrician, predeceased him in 1995 . He leaves two children and four grandchildren. His memory will be commemorated in Barnaul by a plaque at the house where he lived and a bust in the campus of Altai Medical University, and it is expected that the local authorities will name a street in his honour. Pavel Vorobyov

\section{Boleslav Lichterman}

Zinovy Solomonovich Barkagan, haematologist, professor emeritus of Altai State Medical University, Barnaul (b 1925, q Odessa 1946; MD), died from a heart attack on 27 December 2006. 


\section{Richard Hugh Balme}

Former consultant in geriatric medicine East Berkshire district (b 1923; q Oxford 1947; DM, FRCP), died from vascular dementia on 3 December 2006.

After house appointments at The London Hospital, Richard Balme spent two years in the Royal Air Force, mostly in Egypt. After three years as medical registrar at The London and a year at Johns Hopkins Hospital in Baltimore, he led the team from The London's academic unit that introduced haemodialysis for acute renal failure. In 1959 he was appointed consultant physician to the Metropolitan and Bethnal Green Hospitals in east London, introducing gastrointestinal fibreoptic endoscopy and cardiac monitoring and arrest procedures, and setting up one of the first postgraduate centres for general practitioners in the east end. In 1975 he moved to east Berkshire as consultant physician in geriatric medicine, retiring in 1984.

Predeceased by his wife in 1993 , he leaves three children and six grandchildren.

Adam Turnbull

\section{John Rashleigh Belcher}

Former consultant thoracic surgeon North West Thames region and Middlesex Hospital (b 11 January 1917; q St Thomas' Hospital 1939; FRCS, MS), d 13 January 2006. John Belcher was the ninth generation doctor (father to son) in his family, graduating while still aged 21. He joined the Royal Air Force Volunteer Reserve, the experiences of his postings enabling him to gain his FRCS and MS by 1945. John promoted operative treatment of emphysematous cysts and lobectomy for lung cancer, and performed over 1000 closed mitral valvotomies even as fourth operations. He published widely and wrote Thoracic Surgical Management. President of the Society of Thoracic and Cardiovascular Surgeons of Great Britain and Ireland in 1980, with the British Council he set up cardiothoracic units abroad. A devoted family man with wide musical tastes, a compulsive gardener, and an accomplished amateur artist and photographer, he leaves three children; his wife, Jacqueline, died soon after him. P Belcher

\section{Robert Francis \\ Patrick Cronin}

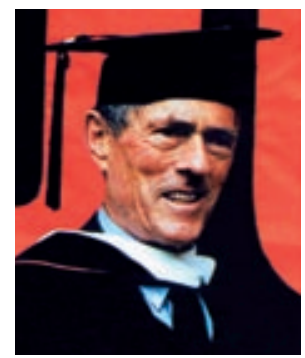

Former professor and dean of medicine McGill University, Montreal, Canada (b 1926; q McGill 1953; FRCP, FRCPC, FACP), died from a heart attack on 13 January 2007.

The son of the author A J Cronin, Patrick Cronin moved to the United States at the outbreak of the second world war. His BA at Princeton was interrupted when he enlisted in the Royal Canadian Air Force in 1943, transferring to the British Army in 1945-7; he gained his BA a record 52 years later. A cardiologist, Patrick was best in broad-based internal medicine. With the Canadian International Development Agency, he set up exchange programmes with developing countries. He helped set up a medical university in Karachi in 1976, serving in the Aga Khan health services for 15 years. In his retirement he collected and collated his father's works. He leaves a wife, Sis (Shirley); three children; and five grandchildren. Krishna Somers

\section{Ernest William ("Bill") Deane}

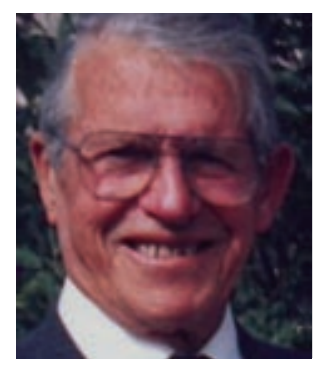

Former general practitioner Christchurch, Dorset (b 1918; q Cambridge/The London 1941; MA), died from heart failure on 18 February 2007.

On qualifying, Bill Deane served as surgeon lieutenant in the Royal Naval Volunteer Reserve until 1946. He then joined his father in general practice in Christchurch, remaining there for 38 years. Outside work, Bill loved sailing, competing in the 1948 Olympic trials and the 1949 Fastnet race. His successes in long distance motor rallies included several alpine and Monte Carlo rallies and winning the RAC rally in 1958. In 1949 he became one of the youngest magistrates, continuing to sit on the Christchurch bench until 1981. A founder member of Christchurch Rotary Club, he was also medical officer to Mudeford lifeboat for many years. He leaves a wife, Ruth, and two children from his first marriage.

\section{Robert Scott-Jupp}

\section{Kathleen ("Kay") Mary de Ville}

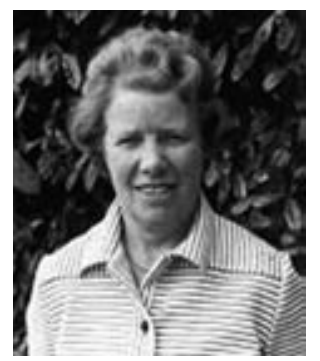

Former prison medical officer (b 1915; q Royal Free 1950), died from bronchopneumonia on 2 August 2006.

Kathleen Mary de Ville ("Kay”) qualified as a state registered nurse from Charing Cross Hospital in 1937. She found the work restrictive so gained a social science diploma from the London School of Economics in 1939. In 1941 she was appointed to the London Probation Service, and in 1943 was able to start medical training. After various house jobs and work as a locum general practitioner she joined the prison medical service, working in Holloway prison, Ashford remand centre, and Feltham borstal, from which she retired in 1975. Kay joined the Society of Friends in 1938 and was an active member of the local Quaker meeting, for a time being an elder. Her husband, Cyril Perry, predeceased her in 1993.

Georgina Stafford

P Jane Grubb

\section{Julie Ann Nash}

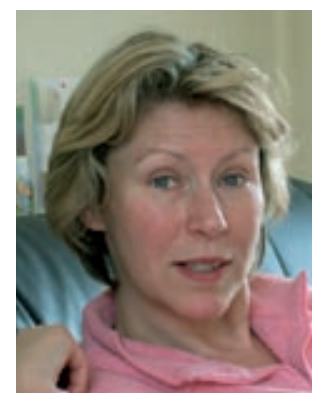

Consultant anaesthetist Whiston and St Helens Hospitals, Merseyside (b 1959; q Liverpool 1982; FRCA), died from metastatic breast cancer on 9 December 2006.

Julie was born in Malta GC but grew up and was educated in Gosport. After qualifying Julie held appointments at Walton Hospital, Liverpool, and then started anaesthetist training in Bradford in 1984, gaining the FRCA in 1990. In 1991 Julie won the Liverpool Society of Anaesthetists' Janssen prize and Forrest medal. She joined the anaesthetic department at Whiston Hospital in 1995, becoming lead consultant for day case anaesthesia. Julie was diagnosed with breast cancer in 2003 and endured a year of intensive treatment. The cancer was in remission until 2006. Julie died in St John's Hospice, Wirral. She leaves her mother, Joan, and two brothers.

Kevin A Nash

\section{ADVICE}

We will be pleased to receive obituary notices of around 250 words. In most cases we will be able to publish only about 100 words in the printed journal, but we can run a fuller version on our website. We will take responsibility for shortening. We do not send proofs. Please give a contact telephone number and, where possible, supply the obituary by email to obituaries@bmj.com 